\section{Exploring the significant role of meta-discourse in academic writing for a discourse community by academic members}

\section{Nasiri, Sina}

Department of English, IAU, Urmia Branch, Iran (sina.nasiri.86@gmail.com)

Received: 8 April 2012

Available Online: 31 May 2012
Revised: 16 May 2012 DOI: 10.5861 ijirse.2012.97

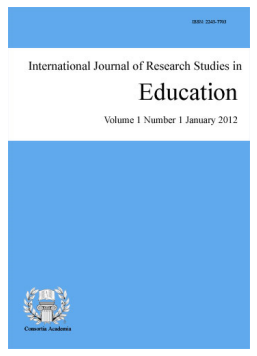

ISSN: 2243-7703 Online ISSN: 2243-7711

OPEN ACCESS

\title{
Abstract
}

Academic writing is kind of writing in which the writers of an academic community try to inform their colleagues about their findings. When they want to write for their communities they should know how to write for. This issue can be outlined by recognizing the underlying features of a particular community and discipline. Recognizing the features is possible through the phenomenon called Meta-discourse. Meta-discourse refers to the aspects of text structure which goes beyond the subject matter and shows the presence of the author, involves linguistic elements which writers use to contribute the acceptability and understandability of the content of the text. Considering the important role of meta-discourse in academic writing, this descriptive study attempts to discover the meaning of meta-discourse and its two main categories, i.e. textual meta-discourse and interpersonal meta-discourse, based on the taxonomy developed by Hyland (1998a). Finally the researcher proposes some of the main issues relating the presence of meta-discourse in texts.

Keywords: particular discipline; textual meta-discourse; interpersonal meta-discourse; conventions; academic writing 


\section{Exploring the significant role of meta-discourse in academic writing for a discourse community by academic members}

\section{Introduction}

Academic writing is normally based on empirical research, which is reported to the scientific discourse community objectively, but with certain conventions. This implies an analytical role on the part of academic writers. In order to meet the demands and expectations of the discourse community in academic writing, complex linguistic maneuvering is required, drawing on textual as well as interpersonal issues (Nasiri, 2011).

Swales (1990) definition of discourse community says that each community has notions such as a "set of common public goals", "mechanisms of intercommunication among its members", and "one or more genres of the communicative furtherance of its aims" (p. 24-27). He also adds that different academic disciplines have developed divers discourse conventions and distinguishes between the discourse paradigms accepted in the business, engineering, journalism, legal, medical, and scientific varieties of "English". Therefore, learners need to learn about their communities' norms and standards.

One of the difficulties experienced by writers in the academic world is related to the understanding what standard is expected in writing for a community. As well as this, each subject discipline has its own ways of doing things and its own conventions about academic writing structure and writing style. For instance, in some subjects it is acceptable to write very personally and put forward your own opinions and feelings on a topic and in others such a personal response would not be appropriate. One needs to find out the expectations and conventions of the addressees in the particular community so that one can write in a way that it is valued within the context of that particular discipline (Nasiri, 2011).

When the researcher wants to write for a community he should consider the norms of the community and maybe this is much more difficult than it sounds. Setting the scene, questions, and the other steps in academic writing are usually written in order to judge one's ability to understand a topic or theme, and to relate ideas to specific applications (or vice versa). In order to demonstrate these things the researcher believes that one must be able to

$>$ correctly identify the conventions of the discipline and

$>\quad$ deal with them consistently and try to stick them in his going way.

But how a writer can notice about the specific conventions of a specific discourse community and accordingly to a specific discipline? Hyland's (2004) claim is a proper answer for this question. He claims that one of the ways of revealing the features of the underlying community is through the writers' use of meta-discourse. This study tries to give an introduction to the meta-discourse and its importance for the writers of a specific community. Therefore, it is hoped that the findings and clarifications of the present study would lead to the way in which researchers can step forwards with awareness. In the next sections of this study, meta-discourse and its subcategories are described and for a general view they will be presented in a table.

\section{Methodology}

\subsection{Design of the study}

This study is a descriptive one which develops through the author's thoughts and understanding of the academic writing and the role of meta-discourse which should be clarified for the researchers belonging to the 
particular discipline.

\subsection{Scheme}

The scheme by which the researcher tries to go through the aim of the study is adopted from Hyland (1998a) which has two main categories, i.e. textual and interpersonal, that they are themselves divided to subcategories.

\section{Exploring the concept of meta-discourse}

The term meta-discourse comes from discourse analysis which refers to the features of a text that clearly relate to the organization of the discourse or to the writer's stance towards either its content or the reader (Hyland, 1998c). Thus, it is the author's manifestation in a text to "bracket the discourse organization and the expressive implications of what is being said" (Schifrin, 1980, p. 231).

In the broad definition by Hyland (2005), meta-discourse is based on a view of writing as social engagement in which writers project themselves into their discourse to signal their attitudes and commitments. In discourse literature meta-discourse is writing about writing (Williams, 1981) or discourse about discourse or communication about communication (Vonde Kopple, 1985); depending on the nature of the discourse investigated, either written or oral.

According to Hyland (1998a), meta-discourse is not dealt with the propositional content of a text but guides or directs readers to how they should understand and evaluate that content. Crismore (1984) takes the similar stance and believes that the aim of meta-discourse is to "direct rather than inform the readers" (p. 280). Vande Kopple (1997) also claims people use meta-discourse to help their readers connect, organize, interpret, evaluate and develop attitudes towards the propositional content.

In a brief utterance, meta-discourse refers to the aspects of text structure which goes beyond the subject matter and shows the presence of the author, involves linguistic elements which writers use to contribute the acceptability and understandability of the content of the text, to be close to the aim of this study, by the readers of a particular discourse community. As Hyland (2005) asserts, writers use meta-discourse to show their opinions and engage with readers as the members of a particular community.

Various taxonomies on meta-discourse elements have been proposed since initial interest began some decades ago (e.g. Vande Kopple, 1985; Crismore, Markkanen \& Steffensen, 1993; Beauvais, 1989; Hyland, 1998a, 2004, 2005; Dafouz, 2003; Markkanen, Steffensen, \& Crismore, 1993). Most of the taxonomies follow Halliday's $(1973,1994)$ tripartite conception of meta-discourse which distinguishes between the ideational elements of a text, that is the ways we encode our experiences of the world, and its textual and interpersonal functions. Halliday (1973) has shown that when people use language, they usually work towards fulfilling these macro-functions of language which are described below:

$>\quad$ The ideational function: the use of language to represent experience and ideas. This function deals with the propositional content.

$>$ The textual function: the use of language to organize the text itself, coherently relating what is said to the world and to the readers.

$>\quad$ The interpersonal function: the use of language to interact with others and to express and understand evaluations and feelings.

Vande Kopple (2002) contends that "primary discourse fulfills Halliday's ideational function and meta-discourse serves Halliday's textual and interpersonal functions of language" (p. 114). Therefore, there are two main categories for meta-discourse; textual and interpersonal (Vande Kopple, 1985, 2002; Hyland 1998a; Crismore et al., 1993). While textual meta-discourse helps writers incorporate and connect bits of ideational 
materials within a text and helping the text make sense in a particular situation for particular readers, interpersonal meta-discourse assists writers to represent their points of views and evaluations of situation they are involved and shows how they hope readers will evaluate the ideational material (Vande Kopple, 2002).

As mentioned before, there are two main categories for meta-discourse. One of the taxonomies represents these categories is the one proposed by Hyland (1998b). He establishes a taxonomy which distinguishes between ten subcategories of meta-discourse, five of which belong to textual meta-discourse and five others to interpersonal meta-discourse. In the following sections the two categories and their subcategories are explained.

\subsection{Textual meta-discourse}

One of the categories of meta-discourse which relates to the texuality is textual meta-discourse. According to Hyland (1998),

textual meta-discourse refers to devices which allow the recovery of the writer's intention by explicitly establishing preferred interpretations of propositional meanings. Devices in this category therefore help form a convincing and coherent text by relating individual propositions to each other and to readers. However, while these items are often considered essential to readability, their use calls attention to the speech act itself and their form depends on the writer's assessment of what needs to be made clear in order to achieve particular goals with a given audience. Textual meta-discourse can therefore represent the degree to which the writer wishes to intrude into the text to restrict the reader's selection of alternative interpretations (Hyland, 1998a, p. 7).

Items in this category performed five main functions which are briefly described based on Hyland's (1998a, c) explanations.

A. Logical Connectives are used to express semantic and structural relation between sentences, without using proper logical connectives the text becomes ambiguous and understanding the transitions between statements will be difficult. Some of the examples of logical connectives are in addition, because, but, however.

B. Frame Markers refer to the text stages and sequences, such as firstly, finally. These markers also serve to indicate topic shifts.

C. Endaphoric Markers are reminders of previously mentioned information or refer to the information in other parts of the text, such as see Fig.1, as noted above, as mentioned before.

D. Evidentials indicate the source of textual information which comes from out of the current text. Writers make use of evidentials to support their statements on the subject matter they are writing, for instance according to $X, Y$ states.

E. Code Glosses provide the reader with additional information as a way of ensuring he is able to recover meanings of ideational material as intended to be conveyed by the writer, such as in other words, namely, such as.

\subsection{Interpersonal meta-discourse}

What is inferred from the term interpersonal is the relationship between the participants in the discourse. To the aim of this study, it is related to the relationship between writer and reader. In this kind of relationship, writer can choose to have emphatic or vague voice toward the propositional information. In addition, writer should consider the rules (conventions) of a particular community for which he/she is writing, for both being polite and as a member of that community (Nasiri, 2011). These interpersonal meta-discourse functions help the writer 
Exploring the significant role of meta-discourse in academic writing

direct the reader into the text and make it more interactional. Not only these functions can be in the hands of the writer but also they give the reader clues about the writer's commitments toward the proposition and assist him to understand the text well. Hyland (1999) emphasizes the functions of interpersonal meta-discourse and states that "interpersonal meta-discourse allows writers to express a perspective toward their propositional information and their readers. It is essentially an evaluative form of discourse and expresses the writer's individually defined, but disciplinary circumscribed persona" (p. 7-8).

Relying on Hyland's (1998c) taxonomy, interpersonal meta-discourse has five subcategories which are explained below.

A. Hedges can be simply defined as the writer's lack of full commitment to the statements and are used by writers in order to leave some rooms for the readers. Hedges are the interpretations or a way of softening the claims of the writers such as may, seem.

B. Emphatics indicates the writer's assurance and his/her confidence in the truth of the propositions, such as in fact, definitely.

C. Attitude Markers represents the writer's evaluation of the propositional information, conveying surprise, agreement, importance and so on such as unfortunately, surprisingly.

D. Relational Markers clearly refer to the relationship with the reader. It directly addresses to the reader and includes the reader into the text. The examples of relational markers are, consider, note that.

E. Person Markers explicitly signal the presence of the author in the text such as $I$, we, my, our. Academic writers usually do not use the pronoun $I$, but they frequently use the pronoun we.

In order to have a glance on the two categories of meta-discourse and their sub-categories; Table 1 has been presented to help reaching this aim.

\section{Table 1}

Taxonomy of meta-discourse in academic texts (adopted from Hyland, 1998a)

\begin{tabular}{|c|c|c|}
\hline Category & Function & Examples \\
\hline \multicolumn{3}{|c|}{ Textual Meta-discourse } \\
\hline Logical Connectives & Express semantic relation between main clauses & $\begin{array}{l}\text { in addition, but, therefore, thus, } \\
\text { and }\end{array}$ \\
\hline Frame Markers & Explicitly refer to the text stages & $\begin{array}{l}\text { finally, to repeat, our aim, here, } \\
\text { we try }\end{array}$ \\
\hline Endophoric Markers & Refer to information in other parts of the text & $\begin{array}{l}\text { noted above, see Fig 1, table 2, } \\
\text { below }\end{array}$ \\
\hline Evidentials & Refer to source of information from other texts & according to X/Y, 1990 / Z states \\
\hline Code Glosses & Help reader grasp meanings of ideational material & $\begin{array}{l}\text { namely, e.g., in other words, such } \\
\text { as }\end{array}$ \\
\hline \multicolumn{3}{|c|}{ Interpersonal Meta-discourse } \\
\hline Hedges & Withhold writer's full commitment to statements & might, perhaps, it is possible \\
\hline Emphatics & Emphasize force of writer's certainty in message & $\begin{array}{l}\text { in fact, definitely, it is clear, } \\
\text { obvious }\end{array}$ \\
\hline Attitude Markers & Express writer's attitude to prepositional content & surprisingly, I agree, $\mathrm{X}$ claims \\
\hline Relational Markers & Explicitly refer to/build relationship with reader & frankly, note that, you can see \\
\hline Person Markers & Explicitly reference to author(s) & I, we, my, mine, our \\
\hline
\end{tabular}




\section{Summary and Conclusion}

Academic writing is generally a kind of evaluation that wants you to indicate knowledge and show proficiency with certain skills of thinking, interpreting, and presenting related to a specific discipline. For instance, English, Mathematics, Psychology, Biology, History, and other disciplines have their own key concepts and language for describing these important ways of understanding. Those key concepts employed in each discipline can be illuminated by the concept of meta-discourse.

Meta-discourse refers to a view of writing in which writers and readers have relationship with each other within a text and this relationship is a social interaction. As the writers write, they negotiate with others, making decisions about the types of impacts they wish to put on their addressees (Hyland \& Tse, 2004). The researcher proposes some of the main issues relating the presence of meta-discourse in texts. He claims that meta-discourse

> can help writers, and particularly academic writers, learn content better,

$>\quad$ is not controlled by native English writers and ESL poor readers and writers (it shares all ideas from the whole globe),

$>\quad$ is used effectively by academic science writers,

$>\quad$ is used differently in different cultures,

$>$ allows written texts to take on some features of spoken language (e.g., personal pronouns to establish an "I-you" relationship), and thus become more reader friendly,

$>$ and allows writers to produce a desired effect, depending on their underlying purposes and perception of readers' expectations.

There are various meta-discourse taxonomies available in the literature. However, the one proposed by Hyland (considered in this study) is the more general one widely used by different scholars. It is known that the choice of meta-discourse expression is highly dictated by the overall structure of the discourse, communicative purpose, and the level of tentativeness or universality of our claims as writers (Salager-Meyer, 1994). In addition to the discipline, learner level and task familiarity, the contribution of these meta-discourse markers is also a function of the language skill we practice, the text type we produce (e.g. argumentative, narrative, etc.), and the constraints of the communicative situation.

Based on recent research in linguistics, explicit instruction can enhance learners' understanding of the features of different disciplines because it shows how language functions for different purposes in different contexts, and how variations are considered appropriate in contexts (Fearn \& Farnan, 2007). Therefore, instructors should teach learners how to write in each discipline; since teaching how to write in a discipline focuses on the generic conventions, including content-specific vocabulary and what counts as evidence or as good organization in a given discipline (Monroe, 2003). Thus, learners learn to write as members of specific discourse communities. In line with these claims, the findings, or in better term the revealing angles, of this study can help teachers and learners of the ESP (English for Specific Proposes) and EAP (English for Academic Proposes) to get familiar with the role of Meta-discourse. In addition, the findings can provide detailed information of the different categories and subcategories for researchers who wish to have voice in their community. Revealing these matters imply that the meta-discourse, from its different items, should be analyzed thoroughly.

In spite of the rich literature in this field, meta-discourse has failed to achieve considerable attention and interest by researchers and applied linguists. The significance of meta-discourse is gradually getting clear in academic writing by writers from different disciplines. Therefore, it is suggested that future studies explore the role of meta-discourse in academic writing in different disciplines in order to make the conventions of those 
Exploring the significant role of meta-discourse in academic writing

disciplines clear for the members of the communities.

\section{References:}

Beauvais, P. J. (1989). A speech act theory of metadiscourse. Written Communication, 6(1), 11-31. <http://dx.doi.org/ 10.1177/0741088389006001002>

Crismore, A. (1984). The rhetoric of textbooks: Metadiscourse. Journal of Curriculum Studies, 16(3), $279-296$. $<$ http://dx.doi.org/10.1080/0022027840160306>

Crismore, A., Markkanen, R. \& Steffensen, M. (1993). Metadiscourse in persuasive writing. A study of texts written by American and Finnish University students. Written Communication, 10(1), 39-71. <http://dx.doi.org/10.1177/0741088393010001002>

Dafouz, E. (2003). Metadiscourse revisited: A contrastive study of persuasive writing in professional discourse. Estudios Ingleses de la Universidad Complutense, 11, 29-52.

Fearn, L., \& Farnan, N. (2007). When is a verb? Using functional grammar to teach writing. Journal of Basic Writing, 26(1), 63-87.

Halliday, M. A. K. (1973). Explorations in the functions of language. London: Edward Arnold.

Halliday, M.A.K. (1994). Introduction to Functional Grammar. London. New York: Edward Arnold.

Hyland, K. (1998a). Exploring corporate rhetoric: Metadiscourse in the CEO's letter. Journal of Business Communication, 35(2), 224-245. http://dx.doi.org/10.1177/002194369803500203

Hyland, K. (1998b). Hedging in scientific research articles. Amsterdam and Philadelphia: Benjamin Publication Company.

Hyland, K. (1998c). Persuasion and context: The pragmatics of academic metadiscourse. Journal of Pragmatics, 30, 437-455. <http://dx.doi.org/10.1016/S0378-2166(98)00009-5>

Hyland,K.(1999).Talking to students: Metadiscourse in introductory course books. English for Specific Purposes, 18(1),3-26. <http://dx.doi.org/10.1016/S0889-4906(97)00025-2>

Hyland, K. (2004). Disciplinary interactions: Metadiscourse in L2 postgraduate writing. Journal of Second Language Writing, 13(2), 133-151. <http://dx.doi.org/10.1016/j.jslw.2004.02.001>

Hyland, K. (2005). Metadiscourse. London: Continuum. Hyland K. \& Tse P. (2004). Metadiscourse in academic writing: A reappraisal. Applied Linguistics, 25(2), 156-177.

$<$ http://dx.doi.org/10.1093/applin/25.2.156>

Markkanen, R., Steffensen, M. S., \& Crismore, A. (1993). Quantitative contrastive study of metadiscourse: Problems in design and analysis of data. Papers and Studies in Contrastive Linguistics, 28, 137-151.

Monroe, J. (2003). Analysis: Writing and the disciplines. Peer Review, 6(1), 4-7.

Nasiri, (2011). A contrastive study of hedges in environmental sciences RAs. Unpublished Masteral thesis. Urmia: IAU, Science and Research Branch, Department of English.

Salager-Meyer, F. (1994). Hedges and textual communicative function in medical English written discourse. English for Specific Purposes, 13(2), 149-170. <http://dx.doi.org/10.1016/0889-4906(94)90013-2>

Schiffrin, D. (1980). Metatalk: Organisational and evaluative brackets in discourse. Sociological inquiry. Language and Social Interaction, 50, 199-236.

Swales, J. M. (1990). Genre Analysis: English in academic and research settings. Cambridge: Cambridge University Press.

Vande Kopple, W. J. (1985). Some exploratory discourse on metadiscourse. College Composition and Communication, 36(1), 82-93.

Vande Kopple, W. J. (1997). Refining and applying views about metadiscourse. Paper presented at the 48'h Annual Meeting of the Conference of College Composition and Communication, Phoenix, AZ. (ERIC Document Reproduction Service No. ED411529).

Vande Kopple, W. J. (2002). Metadiscourse, discourse, and issues in composition and rhetoric. In E. Barton \& G. Stygall (Eds.), Discourse studies in composition (pp. 91-114). Gresskill, NJ: Hampton Press, Inc.

Williams, J. M. (1981). Style: Ten lessons in clarity and grace. New York: Harper Collins Publishers. 
Nasiri, S. 